\title{
Atuação do enfermeiro como educador em saúde junto às mulheres rurais
}

\author{
Amanda Conrado Silva Barbosa, Graziele Carolina de Almeida Marcolin, Mateus Marcolin, Alan \\ Rodrigues de Souza.
}

\section{Resumo}

As mulheres sempre exerceram o papel de cuidadora do lar, provendo a alimentação e assumindo o cuidado com os filhos, quando não, da comunidade. Diante do exposto, percebe-se que a mulher rural, no contexto histórico-cultural, com a responsabilidade de gerar, criar, educar e trabalhar constrói sua visão de mundo. Seus hábitos de vida diária refletem sua condição de saúde, doença e de envelhecimento. Ela trabalha ao lado do marido e filhos na lavoura, exercendo também atividades dentro do lar. Pensando nisso, estudos têm investigado este tema, entretanto, ainda existem muitas lacunas no que concerne ao cuidado em saúde da mulher rural. Por este fato, um estudo voltado à análise de saúde de tal clientela se justifica. Logo, o objetivo propõe identificar ações do enfermeiro correlatas à educação em saúde na prevenção de doenças e agravos em mulheres rurais. A metodologia utilizada foi o relato de experiência, integrando a análise de materiais obtidos por meio de consulta aos Descritores em Ciências e Saúde, sendo diferentes bases de dados acessadas a fim de nortear esta pesquisa. Os resultados evidenciados demonstram que a população rural, no tratamento das mulheres, ainda é defasado, sendo que a promoção e prevenção em saúde não tem ocorrido de maneira efetiva. Foi observado que as Equipes de Saúde da Família, bem como os profissionais de enfermagem devem estar aptos a lidar com diferentes contextos, acolhendo e motivando as diversas populações a buscarem os diferentes tipos de atendimento em saúde. Além disso, a mulher rural ainda apresenta crenças que precisam ser desmistificadas, dando espaço a novas técnicas de cuidado em saúde. As relações sociais, no que diz respeito aos critérios de gênero, são compreendidas nesta pesquisa como relações hierarquizadas, ou seja, relações desiguais que se orientam a partir da dominação masculina sobre a atuação feminina. Além disso, o processo de produção er efetivadas a fim de possibilitar atendimento integral das mulheres rurais. Logo, a atuação diretiva dos mecanismos de saúde no cuidado da mulher rural deve abranger o nível de promoção de saúde e prevenção de doenças. Isso se dá por meio da atuação da ESF e do NASF, uma vez que são mecanismos que integram ações de saúde desenvolvidas por meio de grupos operativos, orientações domiciliares e na unidade de saúde, como também ações diretivas de promoção e prevenção, sendo o enfermeiro, neste contexto, um facilitador do processo de orientação e educação em saúde.

Descritores: Mulher rural; Educação; Saúde. 